\title{
WATER CONSERVATION ABILITY OF THREE SPECIES OF THE GENUS THRICHOMYS (RODENTIA, HYSTRICOMORPHA)
}

\author{
Jeiel Gabrir Carvalhaes ${ }^{1}$, Mariana Moraes Santos ${ }^{2}$, Roberto Leonan Morim Novaes ${ }^{3}$, \\ Ricardo Finotti ${ }^{2,4^{*}}$ and Rui Cerqueira ${ }^{2}$ \\ ${ }^{1}$ Fundação Oswaldo Cruz, IOC, Laboratório de Biologia e Parasitologia de Mamíferos Silvestres \\ Reservatórios. Av. Brasil, 4365, CEP 21040-360, Manguinhos, Rio de Janeiro, RJ, Brasil. \\ ${ }^{2}$ Universidade Federal do Rio de Janeiro, Departamento de Ecologia, Laboratório de Vertebrados. Cidade \\ Universitária, Ilha do Fundão, CP 68020, Rio de Janeiro, RJ, Brasil. c.p.:68020 \\ ${ }^{3}$ Fundação Oswaldo Cruz, Campus Fiocruz da Mata Atlântica, Rede de Pesquisa em Biodiversidade. \\ Estrada Rodrigues Caldas, 3400, CEP 22713-375, Colônia, Rio de Janeiro, RJ. Brasil. \\ ${ }^{4}$ Universidade Estácio de Sá (UNESA), Curso de Engenharia Ambiental e Sanitária - Campus Norte \\ Shopping, Av. Dom Helder Câmara, 508, Pilares, CEP 20771-001, Rio de Janeiro - RJ, Brasil. \\ E-mails:jgabrir@yahoo.com.br,mariana.bio.eco@gmail.com,roberto_leonan@yahoo.com.br, \\ finottiricardo@gmail.com*,rui@biologia.ufrj.br.
}

\begin{abstract}
We tested the water conservation ability of three species of the genus Trichomys that occur in localities with very different climatic regimes, T. fosteri (Pantanal - seasonal wetlands), T. aff. laurentius (Cerrado - savanna) and T. laurentius (Caatinga - shrub land). Individuals were submitted to laboratory urinary concentration experiments using two treatments: one where food and water ad libitum were offered (control experiment - I) and the other of food and water deprivation (test experiment - II). Experiments were conducted during 24 hours and urine volume was collected and measured every 6 hours. We compared the differences in body mass, body mass loss (BML), urine volume (UV), relative urine volume (UVr) and urine osmolality (UO) between treatments for each species and between species for the test experiment (II). The patterns of temporal variation in urine concentration were also analyzed during the experiments. T. fosteri has significantly higher body mass than the other species. Significant differences were found in UV, UVr and UO but not in BML when experiments I and II were compared. Interspecific comparisons showed no differences between species, except for UV, which was correlated with body mass and was higher for T. fosteri. All species presented low mean urine concentration values (T. aff. Laurentius $=1226.14 \pm 608.03 \mathrm{mOsmol} / \mathrm{kg}, T$. laurentius $=1210.02 \pm 662.68 \mathrm{mOsmol} / \mathrm{kg}$, T fosteri $=$ $1301 \pm 541 \mathrm{mOsmol} / \mathrm{kg}$ ) compared to other South American rodents. All species showed high intraspecific variability. Some individuals of T. laurentius reached values of UO higher than $3000 \mathrm{mOsmol} / \mathrm{Kg}$. The temporal patterns of urine concentration from experiments I and II were very similar for all species. Changes in the pattern of urine concentration over time were not observed when comparing experiments I and II. The Thrichomys species studied here seem not to have efficient mechanisms for urine concentration. However, based on the high individual variability and the lack of changes in the short-term temporal variation, this question has to be better analyzed.
\end{abstract}

Keywords: adaptation, body mass loss, semi-arid, urine concentration, water conservation. 


\section{INTRODUCTION}

Species of the genus Thrichomys (Trouessart, 1880) have a complex taxonomic history. It was originally believed to be a monospecific genus (T. apereoides (Lund, 1839)), but in the 1950s and 60s, Moojen (1952), Vieira (1955) and Cabrera (1961) described some subspecies of T. apereoides and named the genus Cercomys. More recent studies based on geometric morphometric (Bandouk and Reis 1995, Reis et al. 2002a, 2002b, Pessôa et al. 2004, Neves and Pessôa 2011), chromosomal (Bonvicino et al., 2002, Pessôa et al. 2004), molecular (Braggio and Bonvicino 2004) and bionomic (Teixeira et al. 2005) traits have demonstrated differences between geographically separate populations. Thus, currently, Thrichomys is considered a complex of eight species (Nascimento et al. 2013). These species are distributed along the open dry and semi-arid vegetational formations of Cerrado, Pantanal and Caatinga, spanning a diagonal from eastern Brazil to Paraguay (FavaroniMendes et al. 2004).

Among these species, T. aff. laurentius (Thomas, 1904), T. laurentius (Thomas, 1904) and T. fosteri (Thomas, 1903) have quite distinct geographical distribution and habitat characteristics. Thrichomys laurentius occurs in semiarid areas (Caatinga), associated with mesic refuges and rocky habitats (slopes of mountain chains and "lajedo" formations), where they find suitable microhabitats with more moderate temperature and humidity levels. Thrichomys aff laurentius can be found throughout the Brazilian northeast, above the São Francisco River, in open shrub land areas. Thrichomys fosteri is found in open areas of Pantanal in Mato Grosso do Sul state, where there is marked seasonality in water availability (Nascimento et al. 2013). Its habitats vary from open vegetation areas and grasslands with isolated trees to typical Cerrado formations with high tree density in forest fragments (Streilen 1982b, Basile 2003).

The ability to conserve body water is one of the most important physiological strategies that enable a small mammal species to live in xeric environments and can help explain the differences in habitat and geographical distribution (Prosser 1973, Mares 1977, Kan and Degen 1988, Beauchat 1990, Beauchat 1996, Schmidt-Nielsen 1996, Ivanova et al. 2000). This characteristic has been studied in small mammals that inhabit xeric environments in South America (Cortés et al 1990, Cortés et al. 1994, Díaz and Ojeda 1999, Shanas et al. 2003, Al-Kahtani et al. 2004, Bozinovic and Gallardo 2006, Díaz et al. 2006) but there are few studies of Brazilian species and its importance in their evolution and geographical distribution (Meserve 1978, Streilein 1982a, Mares et al. 1985, Fonseca and Cerqueira 1991, Cerqueira et al. 2003, Favaroni-Mendes et al. 2004, Ribeiro et al. 2004).

Mammals of the semi-arid Brazilian Caatinga biome supposedly lack water conservation abilities (Mares et al. 1981, Ribeiro et al. 2004). In fact, mean urine osmolality found for species captured in Caatinga sites are usually lower (2193 mOsmol for T. inermis, 
2649 mOsmol. $\mathrm{kg}^{-1}$ for Oligoryzomys nigripes and $2450 \mathrm{mOsmol} . \mathrm{kg}^{-1}$ for Necromys lasiurus) compared to other South American desert rodents, e.g. Spalacopus cyanus - 3300 mOsmol. $\mathrm{kg}^{-1}$, Octogon degus - $4338 \mathrm{mOsm} / \mathrm{kg}$, Phyllotis darwini-4500 mOsmol. $\mathrm{kg}^{-1}$ (Cortes et al. 1998, Bozinovic 1995, Favaroni-Mendes et al., 2004, Ribeiro et al. 2004) and North American and Australian desert species (Notomys alexis $-9.370 \mathrm{mOsmol} / \mathrm{Kg}$, Dipodomys merriane - $5.500 \mathrm{mOsmol} / \mathrm{Kg}$ and Jaculus jacullus - $6.500 \mathrm{mOsmol} / \mathrm{Kg}$ ) (MacMillen and Lee 1967).

However, data on the ability to survive on dry seeds for long periods and on intraspecific differences of body mass loss and urine volume decrease for Thrichomys species can provide an indication of some degree of adaptation to arid conditions, and even being small, they can be significant for habitat and geographical differentiation. Streilein (1982b) found that individuals of $T$. apereoides can live up to 18 days under water deprivation, feeding only on dry grain and losing only $12 \%$ of their body mass. Favaroni-Mendes et al. (2004) compared the ingestive balance of two Caatinga populations of $T$. apereoides (now $T$. inermis (Nascimento et al. 2013)) with different rainfall regimes, in trials with $18 \mathrm{~h}$ food and water ad libitum and water and food deprivation. They found that individuals of the more mesic area have higher body mass, water intake and urine volume excretion than individuals from more xeric ones, but did not find differences in urine concentration. This lack of high urine osmolality values is generally viewed as a consequence of the low evolutionary time that these species have had to adapt to arid conditions (Mares 1977, Streilein 1982b, Ribeiro et al. 2004).

Some studies have shown that in laboratory rats, changes in urine concentration correlate with circadian cycles. When water and food are available, rats have higher urine flow and more diluted urine during activity periods (at night), and lower urine flow in higher concentrations during inactive periods (during the day) (Christensen and Agner 1982). Moreover, they also observed a daily urine concentration variation under normal conditions that still occurs when animals are water deprived.

Here we analyzed the differences in body mass loss, urine excretion and concentration among three Thrichomys species (T. fosteri, T. aff. laurentius and T. laurentius), using water deprivation experiments in the laboratory. We expected they could have different abilities to cope with water deprivation since they occur at regions with very different aridity conditions. We also analyzed and compared the variations in urine osmolality under conditions of food and water ad libitum and food and water deprivation.

\section{MATERIAL AND METHODS}

Individuals were collected from regions with different climatic regimes (Table 1). We used 32 individuals, captured near Parque Nacional da Serra da Capivara, southeast Piauí state; eighteen individuals, collected from the Rio Negro ranch, municipality of 
Aquidauna, Mato Grosso do Sul state (2028'29" S / 55'47'10" W) (Pantanal) 16 T. aff. laurentius individuals, caught in the municipality of Caetité, Bahia state $\left(14^{\circ} 03^{\prime} 45^{\prime \prime} \mathrm{S}-42^{\circ} 29^{\prime} 10^{\prime \prime} \mathrm{W}\right)$ (transition between Caatinga and Cerrado biomes).

The animals were brought to the Vertebrates Laboratory of Rio de Janeiro Federal University and placed in plastic cages (414 x $344 \times 168 \mathrm{~mm})$ cages and maintained under standard laboratory conditions of temperature $\left(22-27^{\circ} \mathrm{C}\right)$, humidity $(50-70 \%)$ and natural photoperiod (Rio de Janeiro city, Brazil). The animals were fed with commercial food pellets (Nuvilab CR1, $12.5 \%$ moisture, $22 \%$ protein, $8 \%$ fiber and $4 \%$ fat) and water ad libitum. They were tested after a period of acclimation of about 40 days in the laboratory. Pregnant and lactating females were not used.

\section{Urinary concentration experiment}

We used modified experimental design from that developed by Fonseca and Cerqueira (1991). The animals were weighed and placed in metabolic cages with collectors containing mineral oil (Nujol). The collector's funnel in each cage was also covered with mineral oil to avoid the urine retention. Urine was collected and its volume was registered every 6 hours in 24-hour trials. The urine collected was stored in a freezer at $-4^{\circ} \mathrm{C}$ in a sealed vial to avoid sample water loss. Urinary osmolality was measured with a freezing point osmometer (Osmomat ${ }^{\circledR}$ 030 - Gonotec).

The animals were visually checked for health conditions during every urine collection period. If some change in an individual's movements and behavior was noted, it was immediately removed from the metabolic cages and put back into a plastic cage with water and food available ad libitum. The animals were housed in metabolic cages for 3 hours during the experiment and the urine excreted during these 3 hours was discarded to prevent possible changes in urine volume and concentrations due to stress. This period was considered the period of metabolic cage acclimation. After 24 hours, the animals were removed from

Table 1. State/biome, minimum (Min) and maximum (Max) monthly absolute temperature $\left({ }^{\circ} \mathrm{C}\right)$, minimum (Min) and maximum (Max) mean monthly precipitation $(\mathrm{mm})$, aridity index (AI) and climatic classes of the localities where each species was collected.

\begin{tabular}{|c|c|c|c|c|c|}
\hline Species & $\begin{array}{l}\text { State/ } \\
\text { biome }\end{array}$ & $\begin{array}{c}\text { Min-Max } \\
\mathbf{T}\left({ }^{\circ} \mathrm{C}\right) \\
\end{array}$ & $\begin{array}{c}\text { Min-Max } \\
\text { Prec. }(\mathbf{m m})\end{array}$ & AI & $\begin{array}{c}\text { Climatic } \\
\text { class }\end{array}$ \\
\hline $\begin{array}{l}\text { Thrichomys aff. } \\
\text { laurentius }\end{array}$ & BA/Cerrado & $19-35$ & $5-290$ & 0.56 & $\begin{array}{c}\text { Dry } \\
\text { Sub-humid }\end{array}$ \\
\hline Thrichomys laurentius & $\mathrm{PI} /$ Caatinga & $13-31$ & $5-180$ & 0.32 & Semi-Arid \\
\hline Thrichomys fosteri & MS/Pantanal & $13-31$ & $0-240$ & 0.84 & Humid \\
\hline
\end{tabular}


the metabolic cages, weighed again and placed in plastic cages with food and water ad libitum. During the first experiments, funnels were checked for urine retention and urine retention was found to be negligible compared to total urine excreted $(0.2 \pm 0.04 \mathrm{~mL})$. Afterward, this was only checked but not measured.

Each individual was subjected to two types of experiment, namely: Control Experiment (I) - when the animals had access to food and water ad libitum during 24 hours; and Test Experiment (II) - when the individuals were deprived of food and water for 24 hours.

Data were tested for normality using the Komolgorov-Smirnov (D) test (Zar 1996). Body mass, body mass loss (BML), urine volume (UV) (mL/ day), relative urine volume (UVr) $\left(\mu 1 . h^{-}\right.$ $\left.{ }^{1} .100 \mathrm{~g}^{-1}\right)$ and urine osmolality (UO) $(\mathrm{mOsmol} / \mathrm{kg}$ ) were calculated. The BML was calculated as the ratio between the final body mass and the initial body mass, UV was the sum of urine excreted by an individual during all the experimental periods. These parameters and UVr were converted using the arcsine square root to achieve normality. Body mass and UO were natural log-transformed to achieve normality. Body mass, BML, UV, UVr, UO were compared between experiments for each species using repeated measures ANOVA. Urine osmolality temporal variation for each species in each experiment (I and II) was analyzed by testing the differences between the experiment hours also using repeated measures ANOVA. All data were analyzed using the Statistica package (StatSoft Inc. Statistica 7.0.).

Differences between species were analyzed by ANOVA and the Tukey post-hoc test for unequal N (HSD). The urine volumes excreted at each time period were correlated with the respective urine osmolality (UO) in both experiments by linear regression for each species (Zar 1996).

\section{RESULTS}

No significant differences were found between gender for T. laurentius, T. fosteri and T. aff. laurentius for BML $(\mathrm{n}=2, \mathrm{~F}=0.73, \mathrm{p}=0.54, \mathrm{n}=2, \mathrm{~F}=$ $0.45, \mathrm{p}=0.25, \mathrm{n}=2, \mathrm{~F}=0.55, \mathrm{p}=0.32$, respectively), $\mathrm{UVr}(\mathrm{n}=2, \mathrm{~F}=0.44, \mathrm{p}=$ $0.35, \mathrm{n}=2, \mathrm{~F}=1.35, \mathrm{p}=0.14, \mathrm{n}=2, \mathrm{~F}$ $=2.33, \mathrm{p}=0.11$, respectively) and $\mathrm{UO}$ $(\mathrm{n}=2, \mathrm{~F}=1.75, \mathrm{p}=0.22, \mathrm{n}=2, \mathrm{~F}=$ $0.35, \mathrm{p}=0.23, \mathrm{n}=2, \mathrm{~F}=1.23, \mathrm{p}=0.13$, respectively), so data were grouped.

All the variables analyzed showed high intraspecific variation (Table 2). Individuals of $T$. fosteri showed significantly greater body mass than individuals of other species $(\mathrm{n}=3, \mathrm{~F}=$ $37.67, p<0.01$ ), being about 1.62 times larger than those of $T$. aff. laurentius $(\mathrm{H}=2.98, \mathrm{p}<0.01)$, and about 1.64 times bigger than $T$. laurentius $(\mathrm{H}=$ 3.62, $\mathrm{p}<0.01$ ) (Table 2). Thrichomys. aff. laurentius and T. laurentius did not differ significantly considering body mass $(\mathrm{H}=8.95, \mathrm{p}=0.35)$. Total urine volume excreted was significantly correlated with body mass in both experiments (I: $r=0.50, p<0.01$ and II: $r=0.53, p<0.01)$.

None of the species showed significant body mass loss between 
experiments I and II (Wilks lambda $=$ $0.70, \mathrm{~F}(40)=0.30, \mathrm{p}=0.59$ for $T$. aff laurentius; Wilks lambda $=0.53, \mathrm{~F}(62)$ $=2.53, \mathrm{p}=0.12$ for $T$. laurentius and Wilks lambda $=0.84, \mathrm{~F}(34)=0.93, \mathrm{p}$ $=0.34$ for $T$. fosteri) (Table 2). Mean $\mathrm{UV}$ and UVr were significantly greater in experiments I for the three species (for UV: Wilks lambda $=0.65, \mathrm{~F}(32$ ) $=11.2, \mathrm{p}=0.02$ for $T$. aff laurentius; Wilks lambda $=0.83, \mathrm{~F}(64)=19.69$, $\mathrm{p}<0.001$ for T. laurentius and Wilks lambda $=0.75, \mathrm{~F}(36)=13.21, \mathrm{p}<0.01$ for T. fosteri; for UVr: Wilks lambda $=15.5, \mathrm{~F}(137)=21.29, \mathrm{p}<0.01$ for T. aff. laurentius; Wilks lambda $=$ 13.9, $\mathrm{F}(164)=18.37, \mathrm{p}<0.01$ for T. laurentius and Wilks lambda $=$ 10.4, $\mathrm{F}(86)=4.78, \mathrm{p}=0.03$ for $T$. fosteri) (Table 2). Mean UO was also significantly greater in experiment II for the three species (Wilks lambda $=$ $12, \mathrm{~F}(83)=8.81, \mathrm{p}<0.01$ for $T$. aff. laurentius; Wilks lambda $=17.3, \mathrm{~F}(161)$ $=22.03, \mathrm{p}<0.01$ for $T$. laurentius and Wilks lambda $=8.89, \mathrm{~F}(132)=6.75, \mathrm{p}$ $<0.01$ for Tfosteri). Urine volume and concentration presented a significant negative relationship for all species in both experiments (Figure 1).

Significant differences were found for urine volume in experiment I $(\mathrm{F}=$ $22.38, \mathrm{p}<0.01)$ and experiment II (F $=11.05, \mathrm{p}<0.01)$. T. fosteri produced greater urine volume than $T$. laurentius $(\mathrm{p}<0.01)$ and T. aff. laurentius $(\mathrm{p}=0.01)$, respectively. However, UVr did not differ between species in experiment I $(\mathrm{F}=2.58, \mathrm{p}=0.07)$ and experiment II $(\mathrm{F}=0.33, \mathrm{p}=0.72)($ Table 2$)$. Also, no significant differences were found in UO between species in experiment I (F
$=1.32, \mathrm{p}=0.27)$ and experiment II (n $=174, \mathrm{M}=0.52, \mathrm{p}=0.59)$. Mean UO in experiment II varied from 1210 for T. laurentius to $1328 \mathrm{mOsmol} / \mathrm{Kg}$ for T. fosteri (Table 2).

No significant differences were found for the temporal variation of urine excreted at each time period and the pattern found for each species between experiments was the same (for $T$.aff. laurentius: Wilks lambda $=0.72, \mathrm{~F}(58)=1.71, \mathrm{p}=0.13$; for $T$. fosteri: Wilks lambda $=0.82, \mathrm{~F}(6.120)$ $=2.14, \mathrm{p}=0.054$, and for T. laurentius: Wilks lambda $=0.93, \mathrm{~F}(132)=0.81$, $\mathrm{p}=0.56$ ) (Figure 2). The maximum osmolality value found was 3226 $\mathrm{mOsmol} / \mathrm{Kg}$ for an individual of $T$. laurentius in experiment II after 24 h. Except for this individual, and two individuals of this same species that reached $3153,5 \mathrm{mOsmol} / \mathrm{Kg}$ and $3224,5 \mathrm{mOsmol} / \mathrm{Kg}$ in the same experiment and period, respectively, and a $T$. fosteri individual that reached $3055 \mathrm{mOsmol} / \mathrm{Kg}$ in experiment II after $6 \mathrm{~h}$, no other individual of the three species studied here reached or passed $3000 \mathrm{mOsmol} / \mathrm{Kg}$.

\section{DISCUSSION}

All the three species studied here increased urine concentration and reduced urine flux and water loss under water and food deprivation. However, mean urine concentration values found under stressful conditions, for all the three species, were lower than those found for other South American species (2071 to $8773 \mathrm{mOsmol} / \mathrm{Kg}$ ) (Bozinovic et al. 1995, Diaz and Ojeda 1999), 

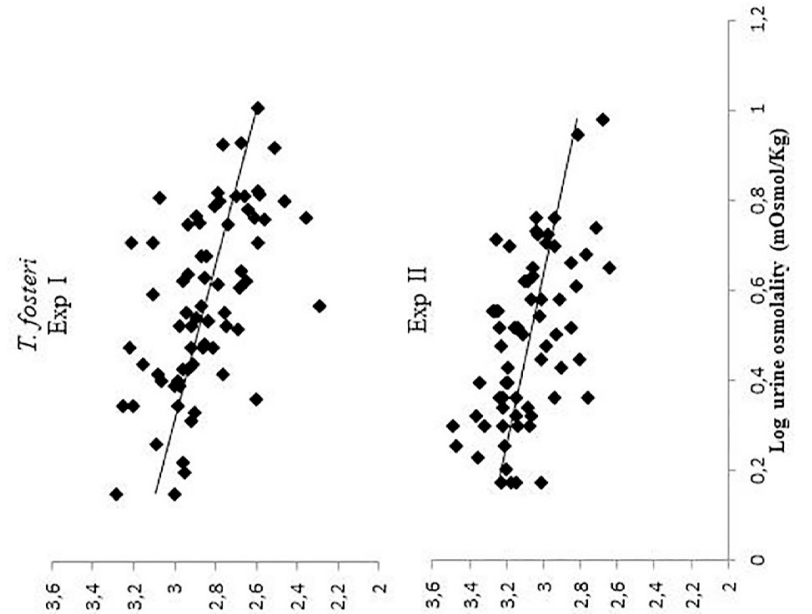

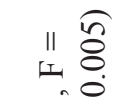

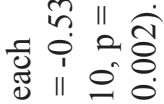

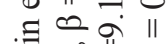

is 6 III

.

过

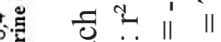

ల్ల

ธิธี㐅ิ กิ่

की - ?

$48 \|$

웅

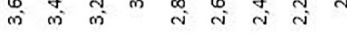
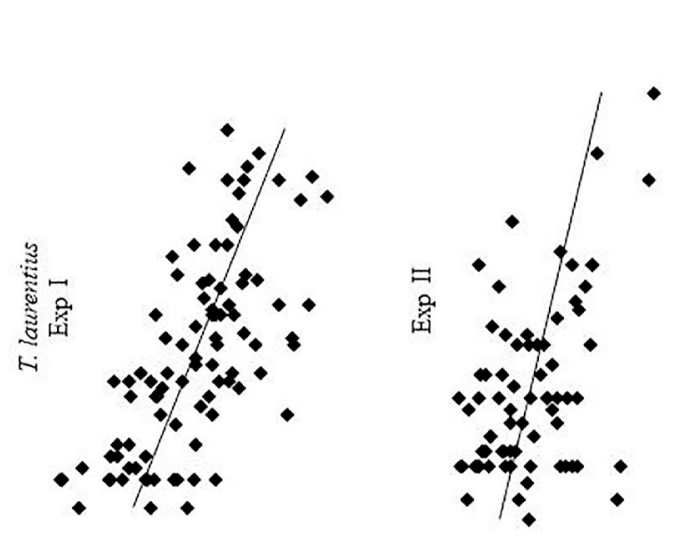

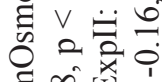

[ ${ }^{-1} \Xi \underset{+}{\infty}$

릅흔

○̊

产

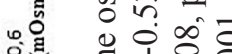

它

‡

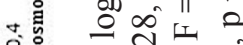

\% च छ

잉

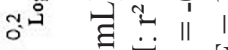

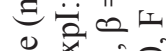

离 Nิ゚์

尚

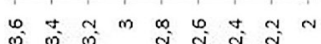

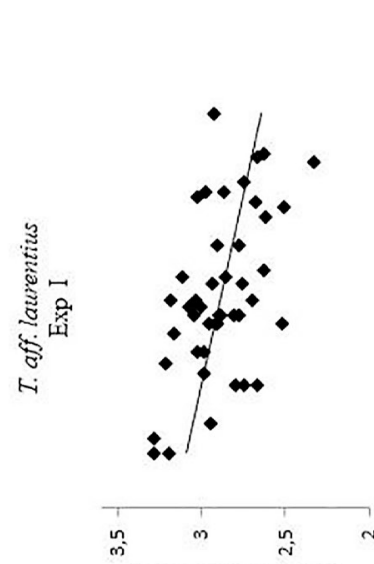

(Jui) aunjos aut.m gor]

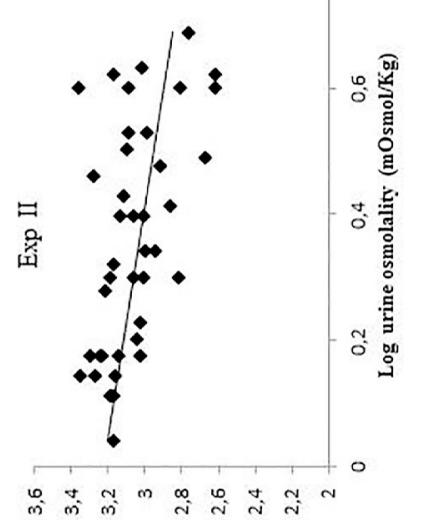

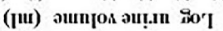

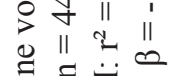

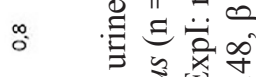

की

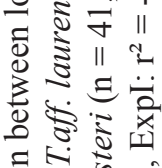

구ำ

की I.

$\dot{0} \dot{\theta}$

卷芯

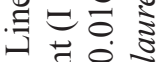

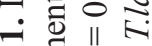

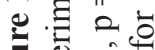

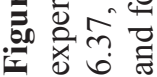




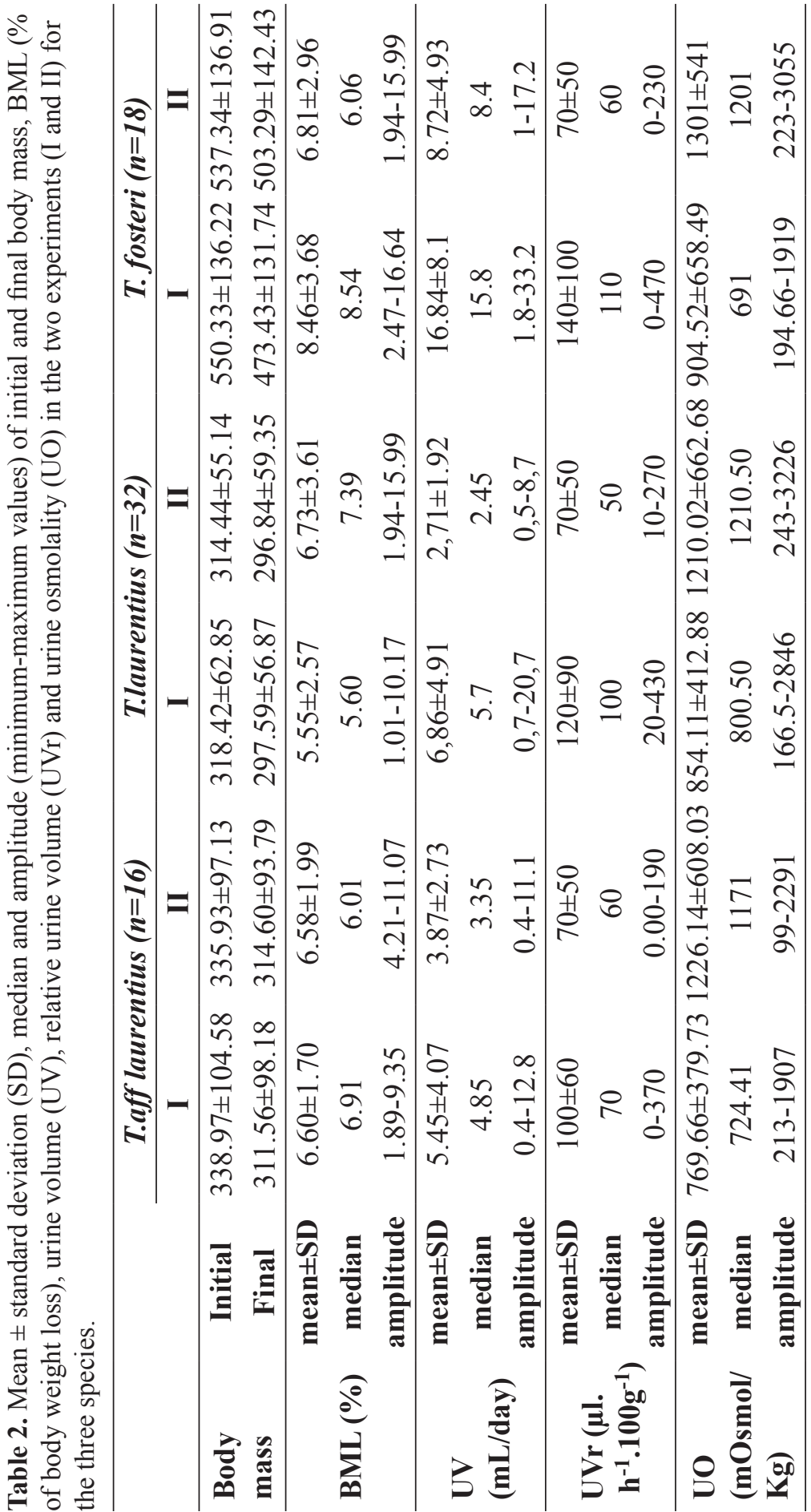




\section{T. aff Laurentius}

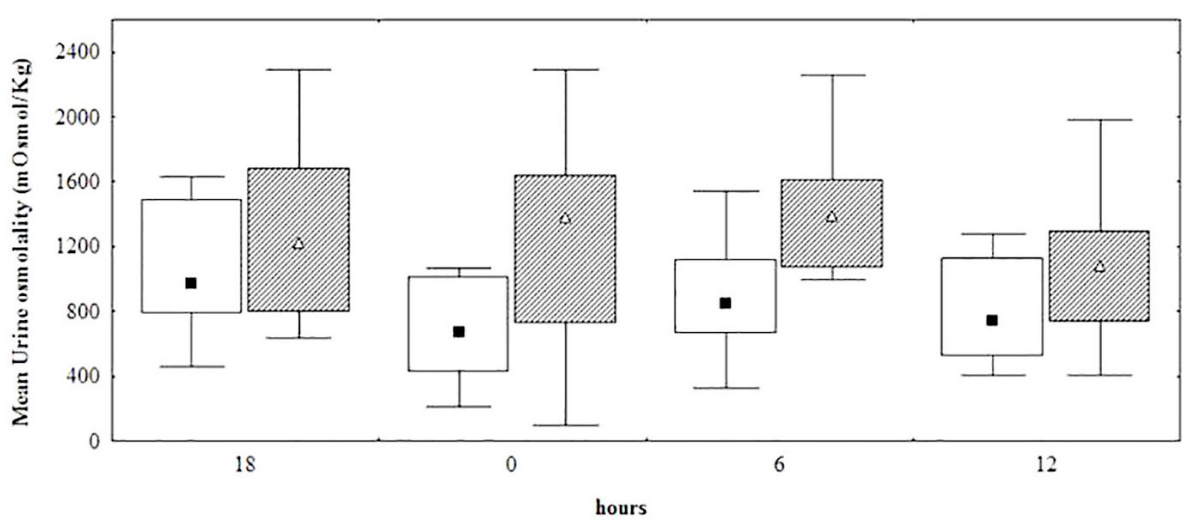

T. Laurentitus

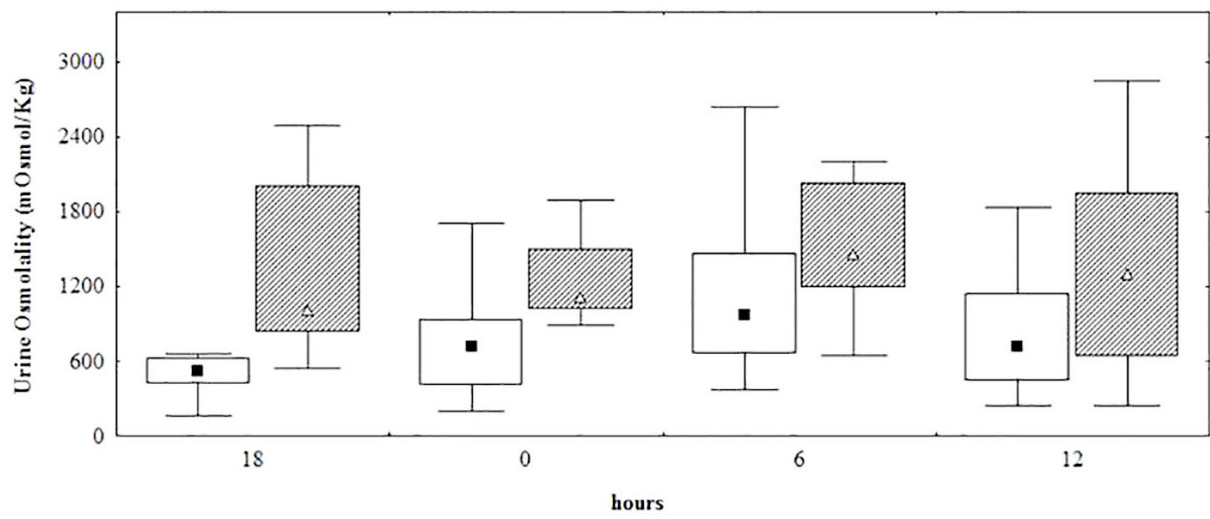

T. fosteri

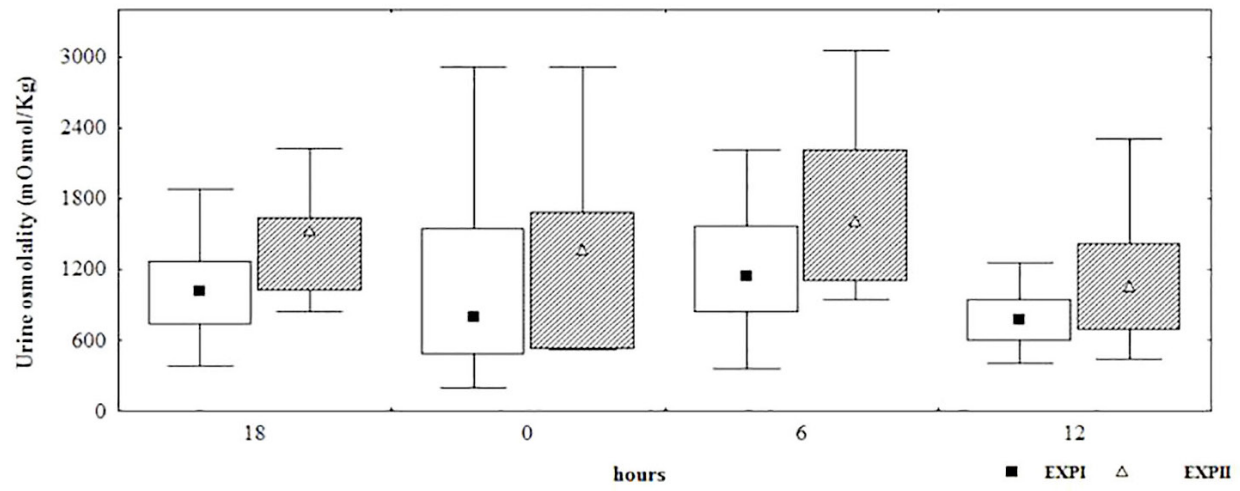

Figure 2. Temporal variation of urine osmolality with ad libitum food and water experiments (I) and water and food deprivation experiments (II) for the three Thrichomys species. Points represent means and bars represent 95\% confidence limits. 
including populations of Trichomys inermis, a species that inhabits dry areas and can reach mean urine concentration of $2193 \pm 340 \mathrm{mOsmol}$ after $18 \mathrm{~h}$ of water and food deprivation (Favaroni-Mendes et al. 2004). High individual variability was noted in all parameters analyzed except BML. The coefficient of variation for UV, UVR and UO varied from $41 \%$ to $71.42 \%$ for all species considering the two experiments. Three individuals of T. laurentius (Caatinga) and one of $T$. aff. laurentius reached values as high as $3000 \mathrm{mOsm} / \mathrm{Kg}$ after $24 \mathrm{~h}$ of water and food deprivation. Such high phenotypic plasticity is probably related to some degree of adaptation to xeric conditions, at least for T. laurentius, and there is potential for the development of these characteristics during periods of water shortage for the other Thrichomys species (Ribeiro et al. 2004, Bozinovic and Gallardo 2006).

The three Trichomys species studied here differed in body mass. Small body mass has been considered a strategy to deal with water restrictions (Lindstedt and Swain 1988, Nevo 1989, Degen 1997). However, they presented very similar physiological responses under water and food deprivation and did not differ in the parameters analyzed (except for UV, which was correlated with body mass). This result was not expected, as the species are from regions with very different aridity conditions.

It is possible that Caatinga species posses no "extraordinary physiological mechanisms for water conservation", as stated by Ribeiro et al. (2004) and hypothesized by Mares et al. (1981) and Streilein (1982b) for South American species. However, Favaroni-Mendes et al. (2004) showed that even individuals of the same species can present differences in urine concentration ability. They compared the ingestive balance, e.g. the balance between the water and food intake and excretion with water and food ad libitum (I) and water deprivation (II) in 18-hour experiments involving two geographically distant populations of Thrichomys inermis under different climatic regimes, and showed that body mass was smaller and urine concentration was greater for the dry habitat population, although the two populations did not differ regarding the other parameters analyzed (UV and UVr). They also showed that these parameters did not change in populations from the dry locale between the two treatments, showing no significant stress during water restriction. Therefore, it is possible that Thrichomys species need to undergo more severe conditions to achieve their maximum urine concentration capacity.

We conducted food and water deprivation experiments during $24 \mathrm{~h}$ and it is possible that individuals were not subjected to stressful conditions during this period, since they did not had significant body mass loss or change in urine concentration with time. So, we can also hypothesize that species were not submitted to conditions necessary to achieve the greatest urine concentration and maybe can withstand this regime for a longer period. It is possible that water and food deprivation periods longer than 24 hours are needed to induce more acute responses in these species. 
The data presented here are representative of the great physiological variability also found in other small South American rodents (Al-Katahni et al. 2004, Bozinovic et al. 1995, Bozinovic and Gallardo, 2006) and also indicate selective forces acting mainly on intra and interspecific variability found in a set of characteristics ranging from body mass to urine concentration physiology. Caatinga is a quite recent vegetation form and presents a highly unpredictable climatic regime, with alternating dry and wet years (Mares et al. 1985, Coimbra-Filho and Câmara 1996). In this scenario, allele frequencies that favor phenotypes adapted to dry and wet conditions can be preserved in Thrichomys populations (Weiner 2006).

We stress the need to analyze not only the urine concentration capacity but also the physiological mechanisms in action when animals are deprived of water (temporal variation in urine concentration at a diversity of organizational levels) (Bozinovic and Gallardo 2006) to understand all the physiological diversity found in small South American mammal species.

\section{ACKNOWLEDGEMENTS}

We are grateful to Nelio P. Barros and Rosana Juazeiro for assistance with the laboratory experiments and general assistance. We also thank two anonymous referees that made substantial comments to help improve. This work was supported by $\mathrm{PPBIO} / \mathrm{CNPq} /$ MMA process no. 457524/2012-0, PROBIO/MMA, FUJB, CAPES, PIE/CNPq, FIOCRUZ and FAPERJ. Licenses for collection, maintenance and experimental procedures were Proc. 02001.000384/00-12 (137/2002 - CGFAU/LIC - 16/12/2002 a 16/12/2003, Proc. 02001.000228/00-99 - 122/2002 - CGFAU/LIC 02/12/2002 a 01/12/2003, Proc. 02001.007437/2002-60 - 0124/002 - CGFAU/LIC - 28/10/2002 a 27/10/2003 and 02022.002062/01-04.

\section{REFERENCES}

Al-Kahtani, M. A., C. Zuleta, E. CaviedesVidal, and T. Garland Jr. 2004. Kidney mass and relative medullary thickness of rodents in relation to habitat, body size and phylogeny. Physiological and Biochemical Zoology 77:346365.

Bandouk, A. C., and S. F. Reis. 1995. Craniometric variation and subspecific differentiation in Thrichomys apereoides in northeastern Brazil (Rodentia: Echimyidae). Zeitschrift fuer Saeugetierkunde 60:176-185.

Basile, P. A. 2003. Taxonomia de Thrichomys Trouessart, 1880 (Rodentia, Echimyidae). Departamento de Filosofia, Ciências e Letras de Ribeirão Preto, Universidade de São Paulo. [In Portuguese]

Beauchat, C. A. 1990. Size medullary thickness, and urine concentrating ability in mammals. American Journal of Physiology 258:298-308.

Beuchat, C. A. 1996. Structure and concentration ability of the mammalian kidney: A correlation with habitat. American Journal of Physiology 271:157-179.

Bonvicino, C. R., I. B. Otazu, and P. S. D'Andrea. 2002. Karyologic evidence of diversification of the genus Thrichomys (Rodentia, Echimyidae). Cytogenetics Genome Research 97: 200-204.

Bozinovic, F. 1995. Nutritional energetics and digestive responses of an herbivorous rodent (Octodon degus) to different levels of dietary fiber. Journal of Mammalogy 76, 627-637.

Bozinovic, F., M. Rosenmann, F. F. Novoa, and R. G. Medel. 1995. Mediterranean type of climatic adaptation in the physiological ecology of rodent species. Pages 347-362. In: M. T. Kalin. Arroyo, P. H. Zedler, and M. D. Fox, editors. Ecology and Biogeography of Mediterranean Ecosystems in Chile, California, and Australia, Ecological Studies. Springer-Verlag (New York, N.Y.) 108:347-362.

Bozinovic, F., and P. A. Gallardo. 2006. The water economy of South American desert rodents: From integrative to molecular physiological ecology. Comparative Biochemistry and Physiology, Part C. 142:163-172. 
Braggio, E., and C. R. Bonvicino. 2004. Molecular divergence in the genus Thrichomys (Rodentia, Echymyidae). Journal of Mammalogy 85:316-320.

Cabrera, A. 1961. Catálogo de los mamíferos de América del Sur. Revista del Museo Argentino de Ciencias Naturales 4:310-732.

Cerqueira, R., R. T. Santori, R. Gentile, and S. M. S. Guapyassú. 2003. Microgeographical ecological differences between two populations of Akodon cursor (Rodentia, Sigmodontinae) in a Brazilian restinga. Journal of Advanced Zoology 24:46-52.

Christensen, S., and T. Agner. 1982. Effects of lithium on circadian cycles in food and water intake, urinary concentration and body weight in rats. Physiology \& Behavior 28 (4):635-640.

Coimbra-Filho, A. F., and I. G. Câmara, 1996. Os limites originais do bioma Mata Atlântica na região nordeste do Brasil. 86p., Fundação Brasileira para a Conservação da natureza, Rio de Janeiro.

Cortes, A., C. Zuleta, and M. Rosenmann. 1988. Comparative water economy of sympatric rodents in a Chilean semi-arid habitat. Comparative Biochemistry and Physiology A 91:711-714.

Cortés, A, Rosenmann, M, and Baez, C. 1990. Kidney and nasal passage functions in body-water conservation of sympatric rodents from central Chile. Revista Chilena de Historia Natural 63(3):279-291.

Cortés, A. P., and C. M. Rosenmann. 1994. Balance hídrico del ensamble de micromamíferos de dos localidades de la región mediterránea árida del norte de Chile central: un estudio de campo. Revista Chilena de Historia Natural 67: 65-77.

Degen, A. A., 1997. Ecophysiology of Small Desert Mammals (Adaptations of desert organisms). 296p., 1st ed. Springer-Verlag, Berlin.

Díaz, G. B., and R. A. Ojeda. 1999. Kidney structure and allometry of argentine desert rodents. Journal of Arid Environments 41:453461.

Díaz, G. B., R. A. Ojeda, and E. L. Rezende. 2006. Renal morphology, phylogenetic history and desert adaptation of South American hystricognath rodents. Functional Ecology 20:609-620.
Favaroni-Mendes, L. A., P. L. B. Rocha, M. F. S. Ribeiro, S. F. Perry, and E. S. Oliveira. 2004. Differences in ingestive balance of two populations of Neotropical Thrichomys apereoides (Rodentia, Echimyidae). Comparative Biochemistry and Physiology, Part A. 138:327-332.

Finotti R., Santori R., Almeida P.J. and Cerqueira R. Comparison of diet and urinary concentration ability of three sigmodontine rodents: an approach to compare the circadian variation and maximal theoretichal urinary concentration. Comparative Biochemistry and Physiology, PART A. submitted on January 2015.

Fonseca, S. D. and R. Cerqueira. 1991. Water and salt balance in South American marsupial, the gray four-eyed opossum (Philander opposum). Mammalia 5:421-432.

Ivanova et al. 2000, comparative structure and function of kidney of the white-footed mouse, Peromyscus leucopus, and the red-backed vole, Clethrionomys gapperi J. Evol. Bioch. Phys. 36(5):567-572.

Kan M., and A. Degen. 1988. Water, electrolyte and nitrogen balances of fat sand rats (Psammomys obesus) when consuming the saltbush Atriplex halimus. Journal of Zoology 215:453-462.

Lindstedt, S. L., and S. D. Swain. 1988. Body size as a constraint of design and function. Pages 93-105 in: M. S. Boyce, editor. Evolution of Life Histories of Mammals. Yale University Press, New Haven.

Lund, P. W. 1839. Blik paa Brasiliens Dyreverden for Sidste Jordomvaeltning. Anden Afhandling: Pattedyrene. Lagoa Santa, d 16d. Novbr. 1837. Det Kongelige Danske Videnskaberns Selskabs Naturvidenskabelige og Mathematiske Afhandling 8:61-144, pls. 1-13. [Preprint of Lund 1841a.]

MacMillen, R. E., and A. K. Lee. 1967. Australian desert mice: independence of exogenous water. Science 158: 383-385.

Mares, M. A. 1977. Water economy and salt balance in a South American desert rodent. Eligmodontia typus. Comparative Biochemistry and Physiology 56A: 325-332.

Mares, M. A., M. R. Willig, and T. E. Lacher Jr. 1985. The Brazilian Caatinga in South American zoogeography: tropical mammals in a dry region. Journal of Biogeography 12: 57-69. 
Mares, M. A., M. R. Willig, K. E. Streilen, and T. E. Lacher Jr. 1981. The mammals of northeastern Brazil: a preliminary assessment. Annals of Carnegie Museum 50: 81-137.

Meserve, P. L. 1978. Water dependence in some Chilean arid zone rodents. Journal of Mammalogy 59: 217-219.

Moojen, J. 1952. Os roedores do Brasil. 231p., 1ed. Instituto Nacional do Livro, Rio de Janeiro.

Nascimento, F. F., A. Lazar, A. N. Menezes, A. M. Durans, J. C. Moreira, J. Salazar-Bravo, P. S. D'Andrea, and C. R. Bonvicino. 2013. The role of historical barriers in the diversification processes in open vegetation formations during the Miocene/Pliocene using an ancient rodent lineage as a model. PLoS ONE 8(4): e61924.

Neves, A. C. S. A., and L. M. Pessôa. 2011. Morphological distinction of species of Thrichomys (Rodentia: Echimyidae) through ontogeny of cranial and dental characters. Zootaxa 2804: 15-24.

Nevo, E. 1989. Natural selection of body size differentiation in spiny mice, Acomys. Zeitschrift für Säugetierkunde 54:81-89.

Pessôa, L. M., M. M. O. Corrêa, J. A. Oliveira, and M. O. G. Lopes. 2004. Karyological and morphometric variation in the genus Thrichomys (Rodentia: Echimyidae). Mammalian Biology 69:258-269.

Prosser, C. L. 1973. Oxygen: Respiration and metabolism. Pages 165-211 in C. L. Prosser Editor. In Comparative Animal Physiology, 3th ed. W.B. Saunders, Philadelphia, PA.

Reis, S. F., L. C. Duarte, L. R. Monteiro, and F. J. Von Zuben. 2002a. Geographic variation in cranial morphology in Thrichomys apereoides (Rodentia: Echimyidae): geometric descriptors and patterns of variation in shape. Journal of Mammalogy 83(2):333-344.

Reis, S. F., L. C. Duarte, L. R. Monteiro, and F. J. Von Zuben. 2002b. Geographic variation in cranial morphology in Thrichomys apereoides (Rodentia: Echimyidae): geographic units, morphological discontinuities, and sampling gaps. Journal of Mammalogy 83(2):345-353.
Ribeiro, M. F. S.; P. L. B. Rocha, L. A. F. Mendes, S. F. Perry, and E. S. Oliveira. 2004. Physiological effects of short-term water deprivation on the South American sigmodontine rice rat Oligoryzomys nigripes and water rat Nectomys squamipes within a phylogenetic context. Canadian Journal of Zoology 82: 1326-1335.

Schmidt-Nielsen, K. 1996. Animal Physiology: Adaptation and environment. 592p., 3th ed. Cambridge: Cambridge University Press.

Shanas, U., D. Afik, M. Scantlebury, and A. Haim. 2003. Differential osmoregulatory capabilities of common spiny mice (Acomys cahirinus) from adjacent microhabitats. Journal of Zoology 261: 7-13.

Streilen, K. E. 1982a. Ecology of small mammals in the semiarid Brazilian Caatinga: climate and faunal composition. Annals of Carnegie Museum 51: 79-106.

Streilen, K. E. 1982b. Ecology of small mammals in the semiarid Brazilian Caatinga: water relations. Annals of Carnegie Museum 51:109-126.

Teixeira, B. R., A. L. R. Roque, S. C. Barreiros-Gómez, P. M. Borodin, A. M. Jansen and P. S. D'Andrea. 2005. Maintenance and breeding of Thrichomys (Rodentia: Echuimyidae) in captivity. Memórias do Instituto Oswaldo Cruz 100(6):527-530.

Thomas, O. 1903. New species of Oxymycterus, Thrichomys, and Ctenomys from S. America. Annals and Magazine of Natural History ser.7, 11:226-229.

Thomas, O. 1904. New forms of Saimiri, Saccopteryx, and Thrichomys from Neotropical region. Annals and Magazine of Natual History 13:250-255.

Vieira, C. C. 1955. Lista remissiva dos mamíferos do Brasil. Arquivos de Zoologia de São Paulo 8: 341-339.

Weiner, J. 2006. O Bico do Tentilhão - Uma História da Evolução nos Nossos Tempos. 462p., 1st ed. ed. Editorial Caminho.

Zar, J. H. Biostatistical Analysis. 662p., 3th ed. Prentice Hall, Upper Saddle River, New Jersey. 